\title{
The Macroeconomic Implications of Consumption: State-of-Art and Prospects for the Heterodox Future Research
}

\section{As Implicações Macroeconômicas do Consumo: Perspectivas para a Pesquisa Heterodoxa}

\author{
Lídia Brochier* \\ Antonio Carlos Macedo e Silva**
}

\begin{abstract}
The recent US economic scenario has motivated a series of heterodox papers concerned with household indebtedness and consumption. Though discussing autonomous consumption, most of the theoretical papers rely on private investmentled growth models. An alternative approach is the so-called Sraffian supermultipler model, which treats long-run investment as induced, allowing for the possibility that other final demand components - including consumption - may lead long-run growth. We suggest that the dialogue between these approaches is not only possible but may prove to be quite fruitful.
\end{abstract}

Keywords: Consumption. Household debt. Growth theories. Autonomous expenditures.

Resumo: O cenário econômico recente dos Estados Unidos motivou uma série de artigos de cunho heterodoxo preocupados com o endividamento das famílias e com o consumo. Apesar de discutirem o consumo autônomo, a maioria dos artigos teóricos se baseia em modelos de crescimento liderado pelo investimento privado. Uma abordagem alternativa é a do chamado supermultiplicador "sraffiano", que aborda o investimento de longo prazo como induzido, permitindo que outros componentes da demanda final - incluindo o consumo - possam assumir a liderança do crescimento de longo prazo. Sugerimos que o diálogo entre essas abordagens não é apenas possível, mas pode se mostrar muito frutífero.

Palavras-chave: Consumo. Endividamento do consumidor. Teorias de crescimento. Gastos autônomos.

JEL Classification: B59; E12; E21.

PhD student at the Graduate Program in Economics of the Institute of Economics, University of Campinas (Unicamp). E-mail: lidiabrochier@gmail.com

$* * \quad \mathrm{PhD}$ in Economics from the University of Campinas (Unicamp). Associate professor at the Institute of Economics, University of Campinas (Unicamp). E-mail: macedo@eco.unicamp.br 


\section{Introduction}

Following Keynes' famous dictum on investment as the "causa causans" of output and employment levels, macroeconomic literature has tended to depict personal consumption as a well-behaved and rather uninteresting aggregate demand component. ${ }^{1}$ To be sure, consumption is much less volatile than investment. But does this really mean it is less important? For many Keynesian economists, the answer is - or at least was, until recently - probably positive. However, the American experience has at least demonstrated that consumption is important, and not only because it usually represents more than $60 \%$ of GDP. In the U.S., the ratio between consumption and GDP has been increasing since the 1980s, in spite of the stagnant real labor income and the growing income inequality. This process, which culminated in the 2007-2008 financial crisis, has motivated a significant number of post-Keynesian papers.

The aim of this paper is twofold. Firstly, to assess this recent surge of papers on household consumption and debt. Secondly, to suggest that granting more attention to consumption (as to other expenditure items beyond investment) can pave new ways for the heterodox research on growth, through the cross-fertilization between the post-Keynesian and the Sraffian agendas. Post-Keynesians, especially by means of stock-flow consistent models, have developed the tools for the rigorous analysis of the financial determinants of expenditure. This is precisely what the supporters of the so-called Sraffian supermultiplier need, so as to improve their models in which variables such as private consumption (or government expenditure) lead growth.

Section two, after this introduction, surveys the recent literature on consumption. Though most of the papers have been published after 2000, pride of place is given to Palley's (1994) seminal contribution.

It may be appropriate to underline that this literature is undeniably "Keynesian" in at least two senses. On the one hand, it features demand-led economies. On the other hand, though dealing with autonomous consumption, it assumes that the demand item that does lead growth is, in the end, "investment" (the only exception being, to our best knowledge, GODLEY; LAVOIE, 2007).

Keynesianism can certainly be associated with the proposition that output is normally constrained by demand. However, in our opinion, this proposition does not imply that demand growth is dominated by the behavior of investment (and ultimately by intangible variables such as confidence and animal spirits). In a business cycle model, or when analyzing a particular historical juncture, to look for

$1 \quad$ It has tended as well to reduce "investment" to business investment, abstracting from its two other major components, public investment and residential investment, which derives from households' decisions and, at least in the United States, is even more volatile than business investment. 
"that factor which is more prone to sudden and wide fluctuation" (KEYNES, 1937, p. 121) is indeed clever advice. When it comes to growth models or to the analysis of somewhat long historical periods, we contend, Keynesian economics can explore different assumptions.

As Keynes himself noticed, the economic system is not as unstable as a naïve reader of the General Theory's first seventeen chapters would expect. Arguably, capacity utilization rates normally fluctuate inside a rather narrow corridor, which to some economists suggests the existence of some adjustment between productive capacity and demand. This, of course, should be no surprise, given that the accelerator continues to be the most robust determinant of investment, often annoying both heterodox and orthodox economists.

However complex they may be, growth models converge (if stable) towards a steady state which is dominated by the behavior of its ultimate autonomous expenditure variable. In the Keynesian tradition, more often than not investment "rules the roost". In this case, even if the model includes (e.g.) autonomous consumption or government expenditure (such as KALECKI, 1954), it must assume that in the long run they grow at the same pace of capital accumulation, which will normally depend on a more or less complicated function in which animal spirits (or innovations) may be the ultimate exogenous factor (and variables such as utilization rate, interest rate and Tobin's q are endogenously determined).

Now, it is pretty obvious that, if one is to obtain a steady state, it is mandatory to assume that the role of "ruling the roost" cannot be shared by two or more variables. There is no steady state if, for instance, investment and government expenditure grow at different rates, for ratios - such as government expenditure and private investment to GDP or (public and private) debt to capital - will not stabilize.

What is not obvious is why Keynesian economists should not tinker with different assumptions. After all, it seems quite clear that, in specific historical situations, the ultimate driver of growth may not be private investment, but residential investment, or personal consumption, or government expenditure, or net exports (as in the Thirlwallian tradition). Models devised to examine such possibilities may then gain in clarity by assuming that private investment is purely induced by demand. Of course, wise economists will neither interpret the steady states their models generate as predictions of what will actually happen in the long run of a real economy, nor will they confuse the simplifying assumption that investment is induced with, for instance, a statement about the inexistence (outside of the model...) of whimsical fluctuations or path-dependence in investment decisions.

In this spirit, in the third section of this paper, we turn to the Sraffian supermultiplier model (SERRANO; FREITAS, 2014), which recently was, so to speak, introduced to the post Keynesian audience by Lavoie (2013). In the model, as the accelerator is the sole determinant of private investment, it is up to other variables 
- such as personal consumption - to explain demand growth. The treatment of investment also implies that, in its "full adjustment" steady state, the rate of capacity utilization is the normal one - which is a traditional bone of contention for heterodox economists. ${ }^{2}$

A brief conclusion - in defense of an ecumenical stance in economic modeling - follows (section four).

\section{Post-Keynesian Literature: Household Debt and its Effects on Growth}

Post-Keynesian works on household debt and its effects on growth differ according to the models' features, the theoretical approach emphasized and the period of analysis considered. However, three convergence points can be easily identified. The first is the main conclusion achieved by most of these papers: household indebtedness process and the build-up of credit-based consumption have unequivocally positive effects on aggregate demand only in the short-run; over the long run they can deliver ambiguous results, depending on income redistribution process generated by debt (see, for example, PALLEY, 1994; DUTT, 2006; CYNAMON; FAZZARI, 2008; BARBA; PIVETTI, 2009; KIM; SETTERFIELD; MEI, 2013).

The second is bringing to the fore the concerns with relative consumption and relative income. Duenseberry and/or Veblen's ideas were recovered to deal with escalating household consumption, despite stagnant labor income. Conspicuous consumption and emulation effect were included in many models to explain debt-led consumption dynamics (BARBA; PIVETTI, 2009; KIM, 2012; VAN TREECK, 2012; RYOO; KIM, 2013; KIM; SETTERFIELD; MEI., 2013; KAPELLER; SCHUTZ, 2014a; 2014b).

The third is the maintenance in most models of the Kaleckian dichotomy between two classes of agents according to the type of income earned: capitalists/ rentists or creditors or high income households, on the one hand, and workers or debtors or low-middle income households on the other (PALLEY, 1994; 2009; DUTT, 2006; HEIN, 2011; KIM, 2012; KAPELLER; SCHUTZ, 2014a; 2014b).

The basic mechanism linking propositions one and two is the following: workers borrow so as to "keep up with" richer workers or with the capitalists, trying to compensate for increasing income inequalities through consumption. The increase in consumption boosts aggregate demand. As borrowing increases, so does the stock of debt and the debt service payments, even if the interest rates are constant. This ends up having a negative effect on aggregate demand growth, since workers' propensity to consume is assumed to be higher than capitalists'. A fortiori, if interest rates grow and workers' income does not keep its pace (see BARBA; PIVETTI,

$2 \quad$ However, it may be interesting to stress that the Serrano and Freitas's (2014) model presents a "medium-run" steady state in which the utilization rate is endogenously determined. 
2009), household financial situation can progressively deteriorate; having started as hedge units, households would (à la Minsky) become speculative and finally Ponzi.

There is much less agreement about the durability of a debt-led consumption regime. Most of the papers present a kind of turning point where the positive effect of workers' borrowing over consumption and aggregate demand is compensated by interest payment transfers to capitalists. The features of this turning point depend on the assumptions of each model.

Despite our focus on the Post Keynesian literature from 2000s onwards, it is only fair to start with a brief mention to a seminal paper by Palley (1994). Building on Kaldor and Minsky, Palley's model investigates whether household debt accumulation increases the likelihood of cyclical instability when the notion of periods of financial tranquility - increasing the willingness of borrowers and lenders to respectively borrow and lend during economic expansions - is incorporated into the model. The answer given is yes.

In the model, debtors' consumption depends on their income net of interest payments and on borrowing - all borrowing is spent - while creditors' consumption depends positively on their income plus debt service payments receipts and, negatively, on lending. It is reasonable, however, to dispense with this last effect, assuming that creditors' consumption is not constrained by cash flows (DUTT, 2006).

The model has been criticized for dealing only with level variables, being thereby incapable of dealing with the evolution of stock-flow and stock-stock ratios. Besides, neither the effects of changes in the propensity to invest on capital stock nor changes in income distribution are considered (HEIN, 2011). One could add that since the model analyzes only short-run fluctuations, it lacks a longer period analysis of consumer borrowing and debt effects over growth dynamics.

After Palley's (1994) initiative, the two core papers dealing with household consumption and debt before the financial crisis were (as highlighted by HEIN, 2011), Bhaduri, Laski and Riese (2006) and Dutt (2005; 2006). Bhaduri, Laski and Riese (2006) follow a Kaleckian-Keynesian approach to analyze how the wealth effect in the stock market could expand aggregate demand through a debt-financed consumption. Dutt $(2005 ; 2006)$ includes consumer debt into a Steindlian growth model to test the hypothesis that increasing debt could reverse the stagnationist trend of a mature capitalist economy. After the financial crisis of 2007-08, most of the papers have focused on income inequality effects on household debt and growth, which suggests a changing emphasis due to the events revealed by the crisis. 


\subsection{How Consumption is Understood: Borrowing, Debt and Wealth}

According to Hein (2011), it is possible to identify three types of modelling approaches to household debt. The first is the multiplier-accelerator business cycle model proposed by Palley (1994). The second is the kind of model built by Bhaduri, Laski and Riese (2006), which focuses on wealth effects on consumption (see also ONARAN; STOCKHAMMER; GRAFI 2011). The third corresponds to growth and income distribution models that emphasize the effects of easier access to credit associated with deregulation of the financial sector, as in Dutt $(2005 ; 2006)$ and possibly in Hein (2011) himself (see also HEIN; DODIG, 2014). In this paper, we add a fourth group, so as to accommodate the works which include both credit and wealth in the consumption function. This approach can be found mainly in Stock-Flow Consistent (SFC) models, as in Godley and Lavoie (2007, ch.11) and Zezza (2008). ${ }^{3}$

In Dutt's (2006) model, there are two types of consumer: workers and capitalists. Workers finance part of their consumption through loans, paying interest to capitalists who save a constant fraction of their income. An important assumption is that profit earners do not need to reduce consumption when they lend. Desired lending is determined by workers' net income. This assumption is criticized by Hein (2011), as it implies that cumulative increases of worker's debt-to-income or debt-to-capital ratios are ruled out and so is potential instability.

Having in mind the U.S. case, Dutt (2006) considers the banking and financial systems' deregulation process and financial innovations as supply side factors that could influence how much consumers borrow. So, if credit is largely available and this pushes households towards borrowing, the stagnation prognosis of the Steindlian-Kaleckian model could be avoided in the short-run. The short-run is defined as the period in which the level of output adjusts to clear the goods' market, while the levels of debt, capital stock and investment are given. In the long run, in which debt, capital and the capital accumulation rate may change, increasing consumer borrowing can have positive or negative effects because increasing consumer debt redistributes income towards the lenders, who save more, thus depressing aggregate demand. This can happen even with constant interest rates; rising interest rates obviously worsen the problem. Some matters left out of the model are acknowledged by Dutt (2006), e.g. workers do not hold assets, capitalists do not take on loans and changes in asset prices and default are not included. It is worth mentioning that Dutt (2006) considers the rate of capacity utilization to be endogenously determined in the long-run and consistent with the notion of long-run equilibrium, where the actual degree of utilization converges to its desired level.

3 The following discussion does not present the papers in the order just mentioned, though the groups are referred to when necessary. 
A pretty similar analysis of consumer debt effects is made by Palley (2009). In a Cambridge-Kaleckian approach, Palley builds a model focusing on growth. The author analyzes both the short-run static implications and the long-run dynamic growth effects of consumer indebtedness in two frameworks, first with exogenous then with endogenous money. Growth is faster in the second case because banks create money, so lending generates a kind of "monetary wealth effect". Still, interest payment transfers from debtors to creditors end up having a negative effect on growth. Palley's (2009) analysis also takes into consideration how interest transfers from debtors to creditors affect the steady state growth path.

Hein (2011) presents an analysis close to Dutt's (2006), including the long-run configuration and results. However, he removes the restrictive hypothesis that capitalists' desired lending is determined by workers' net income. Based on the financialization context, he then assumes that lenders are not worried about borrowers' income when providing credit.

Consumption functions in these papers, aiming at including consumer's debt in growth models, could be expressed as:

$$
\begin{aligned}
& C_{w}=Y_{w}-i D+B \\
& C_{k}=c_{k}\left(Y_{k}+i D\right)
\end{aligned}
$$

Equation (1) is the worker's consumption function and the second equation (2) is capitalist's. Worker's consumption depends positively on wage income $\left(Y_{\mathrm{w}}\right)$ and on borrowing $(B)$, and negatively on interest payment over debt (iD). Capitalist's consumption depends on their propensity to consume $\left(c_{\mathrm{k}}\right)$ out of their income $\left(Y_{k}\right)$, given by distributed profits, and out of interest payment receipts (iD).

In the short run, in which the workers' debt-to-capital ratio is given and constant, a fall in "animal spirits" and a redistribution of income towards the rentiers have depressing effects over capacity utilization and accumulation. Still these effects can be compensated by workers' borrowing for consumption. In the long run, as workers' debt-capital ratio is endogenously determined, if the rate of interest is higher than the profit rate, the positive effects of increased borrowing of workers, seen in the short run, are compensated by the negative feedbacks of the increasing debt and higher interest payments.

Both Dutt (2006) and Hein (2011) believe that borrowing by workers can have positive effects on aggregate demand, through consumption, in the short run. In the medium and long-run, the burden of debt may (or may not) trigger a depressing process on the economy. The inflexion point in the long-run depends on investment parameters. If autonomous investment is relatively weak, it is more likely that consumer indebtedness causes negative effects in the long-run (DUTT, 2006). 
If "animal spirits" of firms do not fall too much (see on this also KIM, 2012), rentier's propensity to save is not too high and interest rates remain low, there could be a worker's debt-to-capital ratio consistent with long-run stable equilibrium if the following condition is satisfied

$$
\alpha>\theta s_{R} i
$$

where $\alpha$ represents the animal spirits of the firms, $\theta$ is the proportion of rentiers' savings going to workers as loans, $s_{R}$ is the rentier's propensity to save and $i$ is the interest rate ${ }^{4}$ (HEIN, 2011).

The fourth kind of approach deals with the influence of both credit and net worth over consumption. Godley and Lavoie (2007) is a good example of growth model with these concerns. Their real consumption function can be represented as follows:

$$
c=\alpha_{1}\left(y d^{e}+n l\right)+\alpha_{2} v_{-1}^{5}
$$

where $y d^{e}$ is real expected disposable income, $n l$ real banks' net lending to households, $\mathrm{v}_{-1}$ household wealth in real terms in the beginning of the period, $\alpha_{1}$ the propensity to consume out of disposable income and banks' net lending to households, ${ }^{6}$ and $\alpha_{2}$ the propensity to consume out of household wealth.

The authors test the effects of three changes in household behavior on growth in the short-run and in the long-run (steady state scenario ${ }^{7}$ ). First, an increase in the propensity to consume out of disposable income and net loans initially accelerates consumption and real GDP, but in the longer-run real consumption and output come back to their initial levels. The permanent effect of a higher propensity to consume in the long-run is a smaller level of household wealth. Second, a greater willingness to borrow also boosts consumption and output in the short-run; however, in the long-run, consumption and output will be lower than the baseline levels. At last, a reduction in liquidity preference (or an increase in the desire to hold equities) will result in higher consumption and output in the short run becau-

$4 \quad$ This condition is necessary for positive long-run equilibrium rate of capacity utilization with a goods' market equilibrium and a stable worker's debt-to-capital ratio (HEIN, 2011).

5 In Godley and Lavoie's (2007) notation, the minuscule variables which are not parameters denote variables in real terms.

6 The assumption of the same propensity to consume out of income and credit seems to be a little unrealistic. The first type of approach mentioned in this section, focused on household borrowing, also assumes the same propensity to consume out income and credit, as workers do not save (DUTT, 2006; HEIN, 2011).

7 The growing economy presented by the model does not reach automatically a steady state in the long-run, but requires active fiscal and monetary policies to achieve full employment without inflation (GODLEY; LAVOIE, 2007). 
se consumption is dependent on wealth - which increases significantly due to capital gains. Again, in the long-run the effect on output disappears due to the fall of gross real investment relative to the baseline, ${ }^{8}$ while real consumption and wealth are still above the baseline scenario. Differently from Dutt (2006) and Hein (2011), in Godley and Lavoie (2007), growth rates are led by pure government expenditures (net of interest payments) and the rate of growth of capital is an endogenous variable, which adjusts to the trend growth rate of these government expenditures.

An interesting approach aimed at investigating empirically the US case is proposed by Zezza (2008). His purpose is to build an SFC model, based on Godley-Lavoie (2007) and Lavoie-Godley (2001-02) approach, to assess the interactions between consumption and saving of two classes of households and two markets - financial and housing markets - in the short and in the long-run (steady state). The consumption function is depicted in detail to account for asset price bubbles in the economy. Capitalist households, the richest $5 \%$, earn profits, interests, rents and wage income; worker households can borrow from banks to finance housing investment and their disposable income is given by wages and interests on bank deposits.

Zezza (2008) proposes two exercises: the first one is to analyze the effects of an increase in expected house prices and the second one is to analyze the emulation effects on consumption. A rise in expected house prices can generate a bubble in the housing market if the supply of new houses does not follow the growth of speculative demand, which attempts to anticipate the increase/decrease in house prices. In the second case, if workers' emulation of capitalist's consumption happens, the model shows an increase in mortgages and a reduction in the saving rate, which is compatible with the stylized facts of the US economy: growth is faster as the overall propensity to save decreases, but the increase in the stock of mortgages to workers' income can destabilize the economy.

In the second approach mentioned in the beginning of the section, we can fit Bhaduri, Laski and Riese (2006) and Onaran, Stockhammer and Grafi (2011). Being mainly concerned with short and medium-run (analysis in terms of growth rates) effects, Bhaduri, Laski and Riese (2006) aim at showing how the financial wealth created in stock markets can boost economic growth through debt-financed consumption. As in Keynes, consumption is presented as a homogenous function dependent on disposable income (net of interest payments) and on borrowing.

$8 \quad$ The drop in the accumulation rate below the trend rate of growth happens due to the developments in the banking system of the model: since banks liquidity ratio decreases due to the reduction in the deposits - as households attempt to buy additional stock market shares -, banks try to recover their liquidity ratios and their profitability, which leads to increases in the deposit rate and in the lending rate. The increase in the lending rate increases the real interest rate, which is one of the accumulation determinants, thus reducing investment in comparison to the baseline (GODLEY; LAVOIE, 2007). 
In contrast to the consumption functions discussed so far, in Bhaduri, Laski and Riese (2006). the mechanism that enables consumer credit to expand is the growth of virtual wealth. i.e. in the stock market. "[...] higher virtual wealth leads to more borrowing by private sector to finance a higher level of expenditure, contributing to aggregate demand. Thus, while the demand-driven real sector expands, it also raises the level of indebtedness of the private sector to the banks and related financial institutions" (BHADURI; LASKI; RIESE, 2006, p. 419).

Onaran, Stockhammer and Grafi (2011) present an interesting approach of the financialization and functional income distribution effects on aggregate demand in the short and in the long-run. According to them, household consumption is the mechanism through which financialization affects macroeconomic activity. The authors build a Kaleckian-Steindlian model in which consumption depends on profit and labor income. The consumption function also includes housing and financial wealth as arguments:

$$
C=c_{0}+c_{\mathrm{w}} Y+\left(c_{\pi r}-c_{\mathrm{w}}\right) \pi_{r} Y+\left(c_{\pi n r}-c_{\mathrm{w}}\right) \pi_{n r} Y+c_{F W} F W+c_{H W} H W
$$

where $c_{0}$ is the autonomous consumption component, $c_{\mathrm{w}}, c_{\pi r}, c_{\pi n r}, c_{F W}$ and $c_{H W}$ are respectively the propensities to consume out of wages, rentier income, non rentier income, financial wealth and housing wealth. $\pi_{r} Y$ is the rentier's portion of income and $\pi_{n r} Y$ is the non rentier's portion of income. FW represents financial wealth and $H W$ housing wealth.

The core conclusion reached by Onaran, Stockhammer and Grafi (2011) is that a redistribution of income towards the rentier group (profit earners) has two main effects that can offset each other: first, it can depress consumption as it diminishes the income of wage earners. Second, it can increase consumption as wealth effects, in financial and housing markets, operate.

Noteworthy is the fact that debt and wealth accumulation are exogenous, and debt and financial wealth are put together in the same explanatory variable for modelling reasons. Consequently, the propensity to consume out of financial wealth and out of borrowing is the same. Since a large part of financial and housing wealth is merely notional (as in the US case), it should be expected that a mechanism, as proposed by Bhaduri, Laski and Riese (2006), would operate to increase credit-based consumption. Onaran, Stockhammer and Grafi (2011) try to capture this element - credit backed by collateral - by considering gross housing wealth ${ }^{9}$ in the consumption function instead of net housing wealth.

In short, the three approaches presented in this section try to capture the elements that determine consumption besides disposable income when handling with

9 According to Onaran, Stockhammer and Grafi (2011) gross housing - including assets and liabilities - accounts better for the debt backed by rising house prices. 
economic growth issues. The first approach focuses on consumer debt, the second one is concerned about both credit and wealth effects on consumption and the last one deals primarily with wealth effects on consumption (even if through credit mechanisms). In the next section, we turn our attention to those papers which try to address the matter from a slightly different point of view, and include relative income concerns (through consumption emulation ${ }^{10}$ ) to account for income inequality effects.

\subsection{The Role of Income Inequalities and the Emulation Effect}

What motivates American households to increase consumption, through borrowing and indebtedness, while their income (most labor income) stagnates or grows slowly? Post-Keynesian literature has found the answer in Veblen's and Duesenberry's formulations. According to Veblen (1899) what guides people's intent to consume is an ideal consumption pattern that is out of reach and what leads people to pursue this pattern is the emulation motive: "the stimulus of an invidious comparison which prompts us to outdo those with whom we are in the habit of classing ourselves" (VEBLEN, 1899, p. 64). Following Duesenberry (1949), household consumption depends on relative income concerns. Households are worried about what other households consume and try to emulate their consumption pattern. Thus, households try to "keep up with the Joneses" and incur in debt because " $[\ldots]$ it is harder for a Family to reduce its expenditure from a high level than for a Family to refrain from making high expenditures in the first place" (DUESENBERRY, 1949, p. 84-85). This is known as the ratchet effect, which means households oppose to reduce their acquired consumption standard (BARBA; PIVETTI, 2009).

Van Treeck (2012) points out that the rising income inequality in the U.S. has called for a "renaissance of the relative income hypothesis of consumption" and highlights the attempt by lower and middle-income households, helped by the increased availability of credit, to keep up with consumption levels of higher income households. Cynamon and Fazzari (2008) had already stressed that household consumption and debt depend on preferences, which are interrelated and driven partially by norms produced by reference groups. The emulation motive can influence both household debt accumulation and household time allocation between work and leisure. Since households' consumption targets are incompatible with their real income, the emulation motive is associated with both qualitative and quantitative changes in household debt accumulation (KIM; SETTERFIELD; MEI, 2013).

$10 \quad$ Even if Zezza (2008) already presents some concern with emulation effects (or what he calls "imitation"), the paper fits the group which deals with credit and wealth simultaneously in the consumption function, since he focuses on the effects of changes in expected asset prices (asset bubbles). 
Barba and Pivetti (2009) stress that the desire to emulate the consumption pattern of the rich could make the poorer work longer hours.

The authors concerned with household debt and increasing income inequality have focused on building models where workers emulate capitalists or rentiers' consumption patterns, to evaluate the effects of an "emulation factor" or a "conspicuous consumption" component over the economy's stability condition. It can thus be said that these papers are dealing with a type of "inter-class" emulation effect (see, for instance, BARBA; PIVETTI, 2009, KIM, 2012, RYOO; KIM, 2013, KIM; SETTERFIELD; MEI, 2013). Barba and Pivetti (2009) seem to consider both inter and intra-class emulation effects when making low income group consumption dependent on current income of the upper class and on the highest income attained by the low-middle income class. This means households base their consumption aspiration not only on the unattainable standard of the richest group, but also on those who are better off but not so distant in the income ladder.

On the other hand, Kapeller and Schutz (2014a, 2014b) focus mainly on the intra-class emulation effect, since they believe that "relative consumption concerns matter primarily within a certain socioeconomic group (e.g. among workers)", introducing "a more realistic assumption on the social mediation of preferences" (KAPELLER; SCHUTZ, 2014b, p. 786). However, this line of reasoning goes against the point made by Cynamon and Fazzari (2008) and Barba and Pivetti (2009), on the "vertical broadening of reference groups". ${ }^{11}$ In a few words, the unattainable pattern/standard of life of the richer leads the rest of the households to go deeper into debt, and for this to happen it is not enough that workers from group one emulate consumption of workers from group two, they need to emulate capitalists' consumption too. Besides, considering that workers emulate capitalists' consumption or that that emulation occurs only within the same income group or still taking into account both assumptions could alter both the sustainability of debt accumulation process, i.e. the time length of the indebtedness process, and the maximum size of household's debt (see KIM; SETTERFIELD, 2013).

In Barba and Pivetti (2009), the consumption function of low and middle-income households includes their current income, the income of the upper class and the highest income obtained by the low-middle income group in the last period. The upper group income is accounted in the ratio $\mathrm{YU}_{\mathrm{U}} \mathrm{Y}^{\mathrm{L}}$, which measures the income inequality through the income ladder. The inclusion of income inequality brings Barba and Pivetti's function closer to Duesenberry's. When that ratio grows, the low and middle income groups direct a greater part of their disposable income to consumption in order to keep up with the Joneses.

The poorer households' emulation of the richer households' consumption is taken into account in most of these papers as an additional term in the consump-

11 This expression can be found previously in the work of Schor (1998). 
tion function and is based on borrowing mechanisms. Kim (2012) develops an SFC model to investigate the macroeconomic impacts of the emulation effect through borrowing in the short-run and in the steady state scenario (which the author calls "medium-run"). His workers' consumption function is represented as:

$$
C_{\mathrm{w}}=\mathrm{W}_{\mathrm{r}} L-i D_{\mathrm{w}}+\beta C_{\mathrm{r}}
$$

Where $W_{r} L-i D_{w}$ is the after-interest disposable income and $\beta C_{r}$ is the term capturing the emulation effect on workers' consumption. The larger the parameter $\beta$, the larger is the rentiers' consumption $\left(C_{r}\right)$ effect on workers' consumption $C_{w}$. Consequently, as workers' budget constraint is given by:

$$
\dot{D}_{\mathrm{w}}=C_{\mathrm{w}}+i D_{\mathrm{w}}-\mathrm{W}_{\mathrm{r}} L
$$

The higher $\beta$, the higher is the consumption financed by debt:

$$
\dot{D}_{\mathrm{w}}=\beta C_{\mathrm{r}}
$$

According to Kim (2012), the emulation effect can lead to an expansion of aggregate demand and, hence, to faster growth. An important assumption is that consumption emulation does not necessarily affects worker's income share negatively. If there is an endogenous wage share target, emulation will have a positive effect on the steady state wage share, since higher consumption expenditures through borrowing and the faster economic growth will endogenously strengthen workers' bargaining power; given the bargaining power of firms, there will be a higher wage inflation. On the other hand, if there is an endogenous profit share target, emulation will have a negative effect on the steady state wage share, since the higher consumption through debt and the higher level of activity will boost firms' profitability and then strengthen firms' bargaining power, increasing the real profit income for a given workers' bargaining power. In the case both targets are endogenous, the effect of emulation on the wage share will be ambiguous: which effect prevails depends on the combination of the relative bargaining power of workers and firms. It seems that the emulation effect reinforces the negative (positive) effect of the weak (strong) bargaining power of workers on the wage share and this leads to increasing (decreasing) income inequalities.

In a similar approach, Kim, Setterfield and Mei (2013) posit that borrowing (B) depends (9) on households desired level of consumption (called "target consumption"). The amount of borrowing (10) will depend on the difference between the desired consumption $\left(C^{T}\right)$ and the consumption provided by wages $\left(C_{w}\right)$ multi- 
plied by a parameter $\beta$, which is sensitive to borrowing norms and financial market lending norms:

$$
\begin{aligned}
& C=C_{w}+C_{r}+B \\
& B=\beta\left(C^{T}-C_{w}\right)
\end{aligned}
$$

The desired level of consumption in turn depends on the level of consumption consolidated in the past, on the current level of consumption of the reference group (in this case the rentier households), and on the expected level of income (dependent on the incomplete set of information, animal spirits and creativity). In the model - which seems to concentrate on the short-term effects, since no long-term period effect is described in the paper - the effects of borrowing and debt on consumption and aggregate demand depend on how households deal with debt service. If debt service works as a "substitute" for savings, meaning that households reduce savings first when debt service increases (instead of reducing consumption), debt accumulation will not become a depressing force on consumption until the critical point where debt servicing surpasses the current savings.

Ryoo and Kim (2013) also consider workers' desire to emulate the rentiers' consumption as a determinant of credit demand. The strength of the emulation effect is measured as a variable $z(t)$ in banks' lending function. Changes in workers' emulation motive then affect credit demand, which can be partially accommodated by banks - the ultimate "roof" to the emulation effect. Following the model implications, a rise in the debt-to-income ratio has negative impacts on workers' net income and consumption and stimulates the emulation motive of workers due to the increase in the gap between the target consumption and actual workers' consumption. However, the growing consumption emulation is limited by the parallel increase in (the level of) indebtedness. In comparison to previous papers, the authors specify in more detail the long-run configuration: they refer to an average rate of utilization, instead of the actual (current) rate, and the long-run average growth rate of capital stock is approximated by the natural rate of growth.

A somewhat different approach is proposed by Kapeller and Schutz (2014b). The authors divide the working class in two groups - type one and type two workers - and assume that a change in income distribution toward profits will happen at the expense only of type two workers. Therefore, a rise in the profit share promotes income inequality within the working class. Besides, when type two workers realize they are falling behind type one workers in income terms, the emulation effect operates. This intra-class emulation effect is treated in the context of a Minsky-Veblen cycle model to analyze the emergence and the burst of the current US crisis. In this case, increasing income inequality reduces the saving rate and 
makes the households resort to increasing consumer credit. During the ascending phase of the cycle, if banks accommodate credit the result is a self-sustaining boom. Nevertheless, increasing debt levels and interest rates decrease disposable income of households, which reduces consumption and triggers the descending phase of the cycle. Since the analysis is restricted to the Minskyan cycle, it seems to have left out the long-run effects of income inequalities and emulation. The basic results of the models including relative income concerns through borrowing are not quite different from the three approaches presented in the previous section. However, the emulation effect contributes to explain how borrowing and consumption grow more than would be expected (if banks accommodate credit demand) based on current income and households' financial situation.

So far we have talked about how these models deal with consumption and debt and, consequently how income transfers can impact economic growth. Yet we have not explicitly discussed how income distribution is understood and how prices are set in these models. In most of them, functional income distribution (that is, distribution between wages and profit), is decided outside the model by conflicting claims between workers and capitalists or by pricing decisions of firms, based on a mark-up on their costs (see LAVOIE, 2014). The mark-up is considered as an exogenous variable in most of these papers (PALLEY, 1994; DUTT, 2006; BHADURI, LASKI; RIESE, 2006; ZEZZA, 2008; HEIN, 2011; KIM; SETTEFIELD; MEI, 2013; KAPELLER; SCHUTZ, 2014). This means they are concerned about the effects of a redistribution between profit and wages on personal income distribution and about how borrowing can lead to income transfers from one group of households which consumes more to another which consumes less, but without any endogenous change in functional income distribution.

Some of these papers also deal with the case in which functional income distribution is affected by borrowing and debt. In order to analyze the effects in this case, the mark-up (and also the profit share) are treated as endogenous to the model. In Palley (2009), the mark-up is affected by changes in capacity utilization, meaning that the effect of household debt on income distribution depends on how debt impacts utilization rates and on how firms react, through the mark-up, to changes in the utilization rate. Kim (2012) follows a different approach, incorporating the bargaining power of workers and capitalists into the model as determining changes in relative prices. Workers and profit earners have, respectively, a target wage share and profit share, and both react to the discrepancy between the actual and the desired income share, which may lead to wage inflation, according to the bargaining power of each group. Ryoo and Kim (2013) consider that income distribution changes endogenously to eliminate the excess demand or supply. ${ }^{12}$

12 Godley and Lavoie (2007) assume that firms make price decisions based on normal cost-pricing, instead of mark-up pricing. Lavoie (2014) argues that both are variants of cost-plus pricing proce- 
The main features of the models presented here and in the previous subsection are arranged in Table 1.

Table 1 - Main characteristics of post-Keynesian literature reviewed

\begin{tabular}{|c|c|c|c|c|c|}
\hline Paper & $\begin{array}{l}\text { Theoreti- } \\
\text { cal ap- } \\
\text { proach }\end{array}$ & $\begin{array}{l}\text { Period of } \\
\text { analysis }\end{array}$ & $\begin{array}{l}\text { Growth } \\
\text { regime }\end{array}$ & $\begin{array}{l}\text { Income } \\
\text { distribu- } \\
\text { tion }\end{array}$ & $\begin{array}{l}\text { Consump- } \\
\text { tion }\end{array}$ \\
\hline Palley (1994) & $\begin{array}{l}\text { Minsky- } \\
\text { Kaldor }\end{array}$ & Short-run & $\begin{array}{l}\text { Demand-led: } \\
\text { investment }\end{array}$ & $\begin{array}{l}\text { Functional: } \\
\text { exogenous }\end{array}$ & $\begin{array}{l}\text { Creditors } \\
\text { and debt- } \\
\text { ors }\end{array}$ \\
\hline Dutt (2006) & $\begin{array}{l}\text { Minsky- } \\
\text { Steindl- } \\
\text { Kalecki }\end{array}$ & $\begin{array}{l}\text { Short-run } \\
\text { and Long- } \\
\text { run (rate of } \\
\text { capacity uti- } \\
\text { lization is en- } \\
\text { dogenously } \\
\text { determined) }\end{array}$ & $\begin{array}{l}\text { Demand-led: } \\
\text { investment }\end{array}$ & $\begin{array}{l}\text { Functional: } \\
\text { exogenous } \\
\text { (mark-up } \\
\text { pricing) }\end{array}$ & $\begin{array}{l}\text { Workers } \\
\text { and capital- } \\
\text { ists }\end{array}$ \\
\hline $\begin{array}{l}\text { Bhaduri et } \\
\text { al. (2006) }\end{array}$ & $\begin{array}{l}\text { Kalecki- } \\
\text { Keynes }\end{array}$ & $\begin{array}{l}\text { Short-run } \\
\text { and medium- } \\
\text { run (Analysis } \\
\text { in terms of } \\
\text { growth rates) }\end{array}$ & $\begin{array}{l}\text { Demand-led: } \\
\text { investment }\end{array}$ & $\begin{array}{l}\text { Functional: } \\
\text { exogenous }\end{array}$ & $\begin{array}{l}\text { Homog- } \\
\text { enous con- } \\
\text { sumption }\end{array}$ \\
\hline $\begin{array}{c}\text { Godley } \\
\text { and Lavoie } \\
\text { (2007, } \\
\text { ch.11) }\end{array}$ & $\begin{array}{l}\text { Post-Keynes- } \\
\text { ian (Keynes- } \\
\text { Kalecki) }\end{array}$ & $\begin{array}{l}\text { Short- run } \\
\text { and long-run }\end{array}$ & $\begin{array}{l}\text { Demand-led: } \\
\text { government } \\
\text { expenditures }\end{array}$ & $\begin{array}{c}\text { Functional: } \\
\text { normal-cost } \\
\text { pricing }\end{array}$ & $\begin{array}{l}\text { Homog- } \\
\text { enous con- } \\
\text { sumption }\end{array}$ \\
\hline Zezza (2008) & $\begin{array}{l}\text { Post-Keynes- } \\
\text { ian (Godley } \\
\text { and Lavoie) }\end{array}$ & $\begin{array}{c}\text { Short-run } \\
\text { and long-run } \\
\text { (steady state) }\end{array}$ & $\begin{array}{l}\text { Demand-led: } \\
\text { investment }\end{array}$ & $\begin{array}{l}\text { Functional: } \\
\text { exogenous } \\
\text { (mark-up } \\
\text { pricing) }\end{array}$ & $\begin{array}{l}\text { Workers } \\
\text { and capital- } \\
\text { ists }\end{array}$ \\
\hline $\begin{array}{l}\text { Barba and } \\
\text { Pivetti } \\
(2009)\end{array}$ & $\begin{array}{c}\text { Duesenber- } \\
\text { ry-Veblen }\end{array}$ & Long-run & - & $\begin{array}{l}\text { Personal } \\
\text { income dis- } \\
\text { tribution* }\end{array}$ & $\begin{array}{l}\text { Consump- } \\
\text { tion func- } \\
\text { tion close } \\
\text { to Due- } \\
\text { senberry's } \\
\text { (relative } \\
\text { income } \\
\text { concerns) }\end{array}$ \\
\hline Palley (2009) & $\begin{array}{l}\text { Cambridge- } \\
\text { Kalecki }\end{array}$ & $\begin{array}{c}\text { Short-run } \\
\text { and long-run } \\
\text { (steady state) }\end{array}$ & $\begin{array}{l}\text { Demand-ledẹ } \\
\text { investment }\end{array}$ & $\begin{array}{l}\text { Functional: } \\
\text { considers } \\
\text { ntilithe casethe } \\
\text { - exogenous } \\
\text { and endog- } \\
\text { enous mark- } \\
\text { up }\end{array}$ & $\begin{array}{l}\text { nereditors. } \\
\text { and deßt-. } \\
\text { ors }\end{array}$ \\
\hline
\end{tabular}

dures and there are no fundamental differences between these variants. 
conclusion.

\begin{tabular}{|c|c|c|c|c|c|}
\hline Hein (2011) & Kalecki & $\begin{array}{l}\text { Short-run } \\
\text { and long- } \\
\text { run (similar } \\
\text { to Dutt's } \\
(2006))\end{array}$ & $\begin{array}{c}\text { Demand-led: } \\
\text { investment }\end{array}$ & $\begin{array}{l}\text { Functional: } \\
\text { exogenous } \\
\text { (mark-up } \\
\text { pricing) }\end{array}$ & $\begin{array}{l}\text { Workers } \\
\text { and rent- } \\
\text { iers }\end{array}$ \\
\hline $\begin{array}{l}\text { Onaran, } \\
\text { Stockham- } \\
\text { mer and } \\
\text { Grafi }(2011)\end{array}$ & $\begin{array}{l}\text { Kalecki- } \\
\text { Steindl }\end{array}$ & $\begin{array}{c}\text { Short-run } \\
\text { and long-run }\end{array}$ & $\begin{array}{l}\text { Demand-led: } \\
\text { investment }\end{array}$ & $\begin{array}{l}\text { Functional: } \\
\text { exogenous }\end{array}$ & $\begin{array}{l}\text { Homog- } \\
\text { enous con- } \\
\text { sumption }\end{array}$ \\
\hline Kim (2012) & $\begin{array}{c}\text { Kalecki- } \\
\text { Duesen- } \\
\text { berry }\end{array}$ & $\begin{array}{l}\text { Short-run } \\
\text { and medium- } \\
\text { run (steady } \\
\text { state) }\end{array}$ & $\begin{array}{l}\text { Demand-led: } \\
\text { investment }\end{array}$ & $\begin{array}{c}\text { Functional: } \\
\text { considers } \\
\text { both cases } \\
\text { - exogenous } \\
\text { and endog- } \\
\text { enous mark- } \\
\text { up }\end{array}$ & $\begin{array}{l}\text { Workers } \\
\text { and capital- } \\
\text { ists (emula- } \\
\text { tion effect) }\end{array}$ \\
\hline $\begin{array}{l}\text { Ryoo and } \\
\text { Kim (2013) }\end{array}$ & $\begin{array}{c}\text { Duesenber- } \\
\text { ry-Veblen- } \\
\text { Kaldor- } \\
\text { Minsky }\end{array}$ & $\begin{array}{l}\text { Short-run } \\
\text { and long-run } \\
\text { (average } \\
\text { long-run utili- } \\
\text { zation rates } \\
\text { converge to } \\
\text { natural rates) }\end{array}$ & $\begin{array}{c}\text { Demand-led: } \\
\text { investment }\end{array}$ & $\begin{array}{c}\text { Functional: } \\
\text { endogenous } \\
\text { mark-up }\end{array}$ & $\begin{array}{l}\text { Workers } \\
\text { and capital- } \\
\text { ists (emula- } \\
\text { tion effect) }\end{array}$ \\
\hline $\begin{array}{l}\text { Kim, Setter- } \\
\text { field and Mei } \\
\text { (2013) }\end{array}$ & $\begin{array}{l}\text { Duesenber- } \\
\text { ry-Cynamon } \\
\text { and Fazzari }\end{array}$ & Short-run & $\begin{array}{l}\text { No growth } \\
\text { (firms do not } \\
\text { invest) }\end{array}$ & $\begin{array}{l}\text { Functional: } \\
\text { exogenous }\end{array}$ & $\begin{array}{l}\text { Workers } \\
\text { and capital- } \\
\text { ists (emula- } \\
\text { tion effect) }\end{array}$ \\
\hline $\begin{array}{c}\text { Kapeller } \\
\text { and Schutz } \\
(2014)\end{array}$ & $\begin{array}{l}\text { Veblen- } \\
\text { Minsky }\end{array}$ & Short-run & - & $\begin{array}{l}\text { Functional: } \\
\text { exogenous } \\
\text { (mark-up } \\
\text { pricing) }\end{array}$ & $\begin{array}{l}\text { Two groups } \\
\text { of workers } \\
\text { (emulation } \\
\text { effect) and } \\
\text { capitalists }\end{array}$ \\
\hline
\end{tabular}

Source: Elaborated by the authors.

Note: * Since Barba and Pivetti (2009) follow a historical approach the definition of functional income distribution as endogenous or exogenous does not apply, but we can still say they are focused on how personal income distribution affects household consumption and debt.

At this point, we can summarize the essential contributions of the approaches addressed so far:

a) In comparison to the standard Keynesian treatment, most of the articles attribute a larger role to the autonomous component of consumption, here understood as the part of consumption that is not dependent on current disposable income, in the short-run and in the long-run, understood as medium-run or long-run, in which the capital stock can grow; 
b) Household debt accumulation effects are analyzed and debt service payments dynamics (its effects on reducing disposable income and as a consumption constraint) is taken into consideration; the emulation boosting effect on consumer credit demand and on indebtedness is also covered.

Some limitations of these papers can also be underlined:

a) Most of the papers analyze household debt and consumption under the assumption that growth is ultimately investment-led. The exception is Godley and Lavoie (2007, ch.11) where government expenditures assume the leading role. Besides, even if long-run effects of household debt and consumption are taken into account, the understanding of the long-run period is not always specified or emphasized. Such imprecision impairs the analysis of changes in income distribution, for one cannot be sure whether they are permanent (long run) effects or transitory.

b) The authors themselves acknowledge some limitations and suggest that improving their models could lead to different results. For instance, in some models, workers do not hold assets Ryoo and Kim (2013), Dutt (2006), and changes in asset prices and default are ruled out Dutt (2006). Another example is found in Ryoo and Kim (2013), where rentier's portfolio preferences are given and this rules out a source of instability, as endogenous changes in portfolio choices can generate instability and cycles and compose a central part of some approaches of Minsky's financial instability hypothesis. At last, Kim, Setterfield and Mei (2013) consider the wealth effects on aggregate consumption are modest and that rentiers do not consume. However, it depends on how the wealth effect on consumption is measured and, certainly, it is important in the US case.

\subsection{Autonomous Consumption as a Source of Demand Growth}

Post-Keynesian literature has primarily focused on the effects of corporate debt during the business cycle or for long-run growth implications (PALLEY, 1994; HEIN, 2011). Still, as already highlighted, there has been a great deal of papers mainly concerned with household debt effects on the business cycle and (less) on the long-run growth process.

As highlighted in the end of the previous subsection, even if credit-based consumption can affect demand during the business cycle, the greater deal of this literature considers the long-run effects on growth to be dependent on investment dynamics. In Dutt (2006), the rate of growth of the economy is given by the investment growth rate. In addition, the magnitude of the autonomous component of 
investment is what determines the consumer borrowing effects on the aggregate demand in the long run: the larger the autonomous investment component, the more likely it will have positive effects. For Hein (2011), the expected sales proxied by the rate of capacity utilization and the "animal spirits" (or state of business confidence) of the firms dictate the rate of investment.

Briefly, credit and wealth-based consumption are induced by debt dynamics in these models and the investment keeps its leading role in the long-run period. In other words, most of the papers are dealing with autonomous consumption expenditures (even if not named like this) when introducing a borrowing component and adding the effects of consumer credit backed by financial and housing wealth. In addition, a few papers go further and explicitly attribute an autonomous component to consumption to account for the unexplained part of consumption (see ONARAN; STOCKHAMMER; GRAFI, 2011; KIM; SETTERFIELD; MEI, 2013; KAPELLER; SCHUTZ , 2014b). Yet, in any case, these autonomous components of consumption are assumed to grow in line with the capital stock growth (SERRANO, 1995; LAVOIE, 2013).

Therefore, Serrano's appraisal still seems to apply:

Autonomous consumption, on the other hand, is usually admitted only in short run [in multiplier-accelerator theorists' approaches] (sometimes some autonomous consumption is formally required to provide 'a floor' or turning point for the cyclical 'downsizing') but in the analysis of long-term growth the autonomous components are simply assumed to grow in line with either the capital stock or the level of income of the economy, usually with the argument that such expenditures must bear some proportion to the size of the economy (SERRANO, 1995, p. 84).

The US recent experience suggests consumption can grow autonomously from current income to a high degree, at least for a while (GUTTMANN; PLIHON, 2008; CYNAMON; FAZZARI, 2008; BARBA; PIVETTI, 2009; BIBOW, 2010; LAVOIE, 2013). The "funding effect" (see BROWN, 2007) of some institutional arrangements provided by financial innovation, as the consumer credit backed by housing collateral, is a good example of how consumption can grow independently of current income growth; and the keeping up with the Joneses is one of the demand motivation for the deb-led consumption surge and development.

Although the main example of economic growth based on consumption is the US, there is some evidence that even China, after the financial crisis of 2007-08, is turning to a consumption-led growth strategy. Since 2011, consumption contributes more than investment for GDP growth. ${ }^{13}$ Besides that, as highlighted by Lavoie (2016), there are some recent papers that try to capture econometrically the

13 In 2011, consumption contributed to around 55\% of GDP growth, while investment contributed to $48 \%$ of GDP growth. For more data on this see China Statistical year book (2015) and China Economic Update (WORLD BANK, 2015). 
causality from the growth of autonomous expenditures to the growth of GDP. Wen (2007) finds some evidence that, for the post-second world war US data, there is a causality that goes from consumption growth to output growth and then to business investment growth. Girardi and Pariboni (2015) also provide some evidence that an increase in the growth rate of autonomous expenditures (exports, government expenditures, residential construction) induces an increase in the investment-to-output ratio, not only for the US case, but also for some European countries (France, Germany, Italy and Spain).

At this point, two questions pop up in mind: what if the capital stock grows in line with autonomous expenditures of aggregate demand? What if autonomous consumption (obviously associated with other autonomous expenditures) takes on the leading role of economic growth in the long-run? This is exactly what has been at heart of the Sraffian supermultiplier approach interests.

Despite the debate of the compatibility between Sraffian and post-Keynesian ideas, Lavoie $(2010 ; 2013)$ brought some of Sraffians' strands back to the Post-Keynesian's circuit. In the next section, we present the Sraffian supermultipler model and point to the compatibility between this kind of model where investment is treated as the "tamed" variable (determined by the accelerator) and the Post-Keynesian approaches presented in section 2.

\section{Autonomous Expenditures and the Long-Run Growth: the Sraffian Supermutiplier Model}

As Kalecki (1967, p. 457) wrote, "capitalists do many things as a class, but they certainly do not invest as a class". They cannot collectively adjust the growth of productive capacity to the growth of demand; under or over investment are unavoidable. Besides, they can only have guesses (either individual or based on conventions) about the growth of demand. As we have learnt from Keynes, uncertainty deeply affects expectations - especially long term ones - making them liable to "sudden and wide" fluctuations. No wonder Kalecki (1968, p. 165) rightfully wrote that the "central pièce de résistence of economics" is the "determination of investment decisions by [...] the level and rate of change of economic activity", as interpreted, we might add, by less than omniscient or even less than rational agents.

The acknowledgement of all these facts does not change another fundamental fact about private investment. The purchase of expensive and quite illiquid capital goods only makes sense if there is demand for the goods to be produced by the increased capacity. Where does this demand come from? One possible answer is that it ultimately comes from the very investment decisions. It is easy to show that in Kalecki (1954), for instance, an autonomous increase in the investment rate of growth accelerates the trend rate of growth and increases the average utilization 
rate; the same applies to many neo-Kaleckian models. Though one might be tempted to say that, in these models, investment is left "hanging by its own bootstraps", we know this is not quite true, for the acceleration of investment may be explained by, for instance, an increase in the rate of innovation.

Our point here is that these results depend crucially on the assumption that every other autonomous item in final demand will end up by growing in line with productive capacity, so that in the steady state ratios such as government expenditure/fixed capital will be stable. However, nothing should prevent us from examining the implications of a different answer to the question we have just posed. That is to say, demand may ultimately come from other final demand item(s). This procedure is perfectly able to deliver stable models which converge towards a steady state, provided we adopt a different (but equally debatable) simplifying assumption, that investment is strictly induced.

This corresponds, of course, to the supermultiplier research program (SERRANO, 1995), which explores the idea that there is a fundamental distinction between capacity-creating private investment and other autonomous expenditure items. Only private investment creates capacity whose "utility" is to be measured according to profitability benchmarks. Other items are not restrained by this constraint. Such is the case of government investment, which does create productive capacity. But it is also the case of residential investment, which does not. In addition, government consumption expenditure and exports (which may well create capacity elsewhere) do qualify as autonomous expenditure. Even personal consumption may (partially) behave likewise, as in the models examined in the previous section.

In the rather simple supermultiplier models developed so far, one (and just one) of these autonomous expenditure items is singled out as the growth engine. The growth rate of such variable, whatever it is, becomes the warranted rate of growth. Investment must follow, if firms are to keep a constant rate of utilization; if investment growth rates are higher (lower) than the growth rate of the autonomous variable, utilization rates will fall (rise).

In the conclusion, we come back to the reasons why these models can, in principle, focus only on a single growth engine, and explain how these models promising, but in fact too simple - can be improved. Before that, we present some features of Serrano's pioneering contribution. 
Serrano (1995) discusses under which conditions and in what sense the economic system as a whole can be demand-led, taking into account the interdependence and the feedback effects that arise from the dual nature of investment and of the circular flow of income. Thus, he proposes a model, called the Sraffian ${ }^{14}$ supermultipler model, in which economic growth is demand-led even in the long-run. In this model, long-term growth depends on the exogenously given rate of growth of an (autonomous) component of demand.

This autonomous demand component can be any final expenditure that does not directly generate private productive capacity. "Autonomy" refers to the fact these expenditures are not induced by contractual income generated by production decisions (wages and salaries). Following this criteria, the expenditures that could be understood as autonomous are: capitalists' consumption; richer workers' consumption ${ }^{15}$ (because they must hold assets, have accumulated wealth and credit access); households' residential investment; discretionary expenditures of firms (which do not include the purchase of production goods), such as consultancy services, Research and Development, publicity, etc.; government expenditures (consumption and investment) and exports (SERRANO, 1995).

It must be emphasized that choosing in the model between private fixed investment and this aggregate demand component as the persistently autonomous variable in the long-run is an important cleavage that does not deny the fact private fixed investment is empirically volatile neither blocks the analysis of autonomous changes in this variable through this model.

For the economic system to be demand-led in Serrano's (1995) framework, two main conditions need to be fulfilled: first, induced investment plus induced consumption must sum less than the unity, that is, the general propensity to spend must be less than one; second, the long-run level of autonomous aggregate demand expenditure must be positive. Formally, these two conditions can be represented respectively as:

$$
\begin{aligned}
& c+h<1 \\
& Z_{t}>0
\end{aligned}
$$

14 The term Sraffian is chosen to account for the assumption that income distribution is exogenous, the prevalence of normal prices and the long-run tendency towards the planned degree of capacity utilization (SERRANO, 1995).

15 Taking the recent US experience into account, it seems rather a restrictive assumption to list only rich workers' consumption as autonomous. It is well known that the institutional arrangements of the financial system allowed for poor households to have access to credit, thus basing part of their consumption not only on wage income. 
where $c$ stands for the marginal propensity to consume, $h$ denotes the marginal propensity to invest and $Z$ represents autonomous expenditures. Equation 12 by itself implies that the average propensity to save will be an endogenous variable, even if the marginal propensity to save and the profit share are constant (more on this below).

Based on Serrano and Freitas (2014), ${ }^{16}$ we can turn to the main assumptions of the model. In this version, the authors adopt the simplifying assumption that $Z$ corresponds to autonomous consumption. Private investment is considered as an induced expenditure and income distribution is exogenously given.

The demand determined output level and the supermultiplier in a long run position are represented as:

$$
Y_{t}=\left(\frac{1}{s-h}\right) Z_{t}
$$

where the expression between parenthesis is the supermultiplier, which captures the level multiplier effects associated with induced consumption or savings, and the accelerator effects derived from induced investment (h). The average propensity to save depends on the marginal propensity to save and on the ratio between autonomous expenditures and income. The marginal propensity to save sets the upper limit of the average propensity to save (SERRANO; FREITAS, 2014).

To make this proposition clearer, we can suppose initially that there are no autonomous expenditures. Thus, for a given income, saving depends strictly on the marginal propensity to save which is equal to the average propensity to save:

$$
S=s Y \rightarrow s=S / Y
$$

In such a case, it is impossible to change the investment rate if the economy system finds itself in an equilibrium position, since

$$
h=I / Y=s
$$

Yet in the supermultiplier model, the marginal propensity to invest changes and the investment rate determines the average propensity to save, which is lower than the marginal propensity to save, because $\mathrm{Z}$ is positive:

$$
h=I / Y=S / Y=s-Z / Y
$$

Now it is easier to notice that the average propensity to save is an endogenous variable and that an adjustment between investment and savings is possible

16 Two different versions of this paper were used to describe the model in this section. 
without implying changes in the marginal propensity to save (s) or in the degree of capacity utilization ( $u$ ), as would be the case in most post-Keynesian models. Besides, the marginal propensity to save defines the upper limit of the average propensity to save, for if $Z_{t}=0$, the maximum value of the average propensity to save will be equal to $s$.

In order to present the main results of Serrano and Freitas (2014), we need to introduce also their equation for the degree of capacity utilization in the steady state:

$$
u^{*}=\frac{v\left(g_{z}+\delta\right)}{h}
$$

where $u^{*}$ is the trend level of capacity utilization, $v$ is the capital-output ratio, $g_{z}$ is the autonomous expenditures (consumption) growth rate, $\delta$ is the capital dropout ratio and $h$ is the marginal propensity to invest.

Differently from preliminary versions of the supermultiplier, i.e. Serrano (1995), Serrano and Freitas (2014) define two configurations of the steady state, or long-run equilibrium. In the first steady state, the adjustment among investment, capital and output is partial because the marginal propensity to invest $(h)$ is given. This implies that, as in neo-Kaleckian models, the degree of capacity utilization is endogenously determined, which is a reasonable assumption since the degree of capacity utilization really fluctuates - even if within a certain corridor. This partial character of the steady state justifies classing it as kind of "medium run" equilibrium. The authors assess the effects on this medium run equilibrium of changes in the autonomous demand growth $g_{z}$, in the wage share (and in the marginal propensity to save $s$ ) and in the marginal propensity to invest $h$.

Looking at equations (13) and (17), a higher rate of growth of autonomous expenditures $g_{z}$ leads to higher growth rates of induced investment, induced consumption and capital, for a given $h$. The degree of capacity utilization $u^{*}$ will also be higher. An increased wage share, or a decrease in the marginal propensity to save $s$, will translate into a higher output $Y_{t}$, (i.e. a level effect). The increase in the degree of capacity utilization will be temporary and the growth trend will still be $g_{z}$. Finally, a higher $h$ will also have a level effect on $Y_{t}$, growth rates will increase temporarily but then will return to $g_{z}$. There will be a permanent effect on the degree of capacity utilization $u^{*}$, which will be lower.

In the second steady state configuration presented by Serrano and Freitas (2014), called fully adjusted position, the marginal propensity to invest $h$ is allowed to move and the degree of capacity utilization tends to the desired degree of utilization. For this steady state to present "full adjustment" the last hypothesis is essential: $u$ must moves towards the desired degree $\mu$ until $u=\mu$. This happens in the model 
because of inter-capitalist competition. Investment will accelerate whenever the actual degree of utilization is higher than the desired degree of utilization: $u>\mu$.

This secular adjustment process is given by

$$
\dot{h}=h_{t} \gamma\left(u_{t}-\mu\right)
$$

In which $\gamma>0$ represents the coefficient explaining the sensitivity of the propensity to invest to deviation of $u$ from $\mu$.

The possibility of output capacity adjustment to aggregate demand, i.e. $h$ changes moving $u$ towards $\mu$, requires that two conditions are satisfied. The first condition is that $h=I / Y$ can really change and this depends of the existence of an autonomous expenditure which does not generate private capacity. The second condition is that $h<s$, which is necessary to make demand-led growth possible.

During the adjustment process of $h$, aggregate demand path can be described by the following equation:

$$
g_{t}=g_{z}+\frac{\dot{h}}{s-h_{t}}
$$

From equations (18) and (19), we can infer that when the degree of utilization is different from the desired degree of utilization $(u \neq \mu)$, output grows at the rate $g_{z}$ plus the change rate of the supermultiplier - the second term of equation (19). This later rate reflects additional change of investment due to changes in the propensity to invest $h$, not due to income changes.

The results reached in Serrano and Freitas (2014) analysis of changes starting from fully adjusted positions are similar to those reached for long run analysis (medium run). An increase in $g_{z}$ has growth effects on output and capacity. However, the adjustment movement of investment triggers a temporary additional increase of aggregate demand with an initial rise in the degree of utilization. According to Serrano and Freitas (2014), afterwards the degree of utilization will oscillate towards the normal degree of utilization $\mu$.

One of the central implications of Serrano's supermultiplier approach is stressed by Lavoie (2013). Even if the marginal propensity to save, the income distribution and the degree of capacity utilization are given, savings can adjust to investment. Thus, the Keynesian hypothesis that savings adjust to investment is broader than usually thought. It does not need the assumption of an endogenous rate of utilization in the long run, as in the Kaleckian approach (or the treatment of income distribution as endogenous, as in Cambrige models).

The main results of the model also highlight that changes in the autonomous expenditures growth rate have permanent effects on growth rates of output and capacity, while changes in the determinants of the propensities to consume or save 
have only permanent level effects on output and capacity. Besides, the results are quite similar in both scenarios considered: the steady state with incomplete adjustment (medium run) and the steady state with complete adjustment (fully adjusted positions, long run) (SERRANO; FREITAS, 2014).

\subsection{The Supermultiplier and the post-Keynesian Debate}

The supermultiplier model was brought to the Post-Keynesian debate by authors as Lavoie (2013) and Allain (2012). In fact, Serrano and Freitas (2014) believe it is reassuring the fact that neo-Kaleckian authors, like Lavoie (2013) and Allain (2012), though adopting a distinct approach, reach conclusions that are quite similar to theirs. Both authors deliver analyses of the sufficient conditions for stability of a demand-led growth regime close to that presented in Serrano and Freitas (2014). Besides, Lavoie (2013) and Allain (2012) also find that a gradual adjustment of investment share when the actual degree of utilization differs from the normal degree of utilization is compatible with dynamics stability. The central difference between these neo-Kaleckian approaches and Serrano's is related to the interpretation of long-run equilibrium (SERRANO; FREITAS, 2014).

When dealing with the controversies about utilization rates in the longrun in Kaleckian models, Lavoie (2013) ${ }^{17}$ devotes some pages to the Sraffian supermultiplier, where he presents a "simple" proof of the necessary conditions for the model's mechanism to be valid. The supermultipler model can be used to divide two strands of Sraffians: those who, like Serrano, support the supermultiplier analysis with its normal capacity utilization rates (see BORTIS, 1997; CESARATTO; SERRANO; STIRATI, 2003; DEJUAN, 2014) and those who deny that the capacity utilization rates stay at their normal levels in the long run, either continuously or in average (See CICCONE, 2011; PARK, 2000; PALUMBO, 2013; TREZZINI, 2011).

According to Lavoie (2013), the first point made by Serrano - that even with the marginal propensity to save, the income distribution and the utilization rate as constants, saving can adjust to investment - is confirmed due to the stabilizing mechanism created by this exogenous autonomous growth component. However, the second point, claiming that average rate of capacity utilization will tend towards its normal rate and the economy will approximate a fully adjusted position, is questionable.

According to Lavoie, if the economic system departs from a fully adjusted position it is unlikely it will remain there and when the economic system moves away from the fully adjusted position it is also unlikely it will come back to that position. Thus, the average capacity utilization rate cannot be equal to the normal capacity utilization rate (LAVOIE, 2013).

17 This paper is now part of Lavoie (2014). 
Another observation is that in Serrano's model there is no room for the discussion of wage-led versus profit-led growth regimes. Namely, the growth rate of capital adjusts to the autonomous expenditure growth rate and the long-run value of capacity utilization does not depend neither on the profit share nor on the propensity to save out of profits (LAVOIE, 2013). In other words, growth and distribution are independent variables, i.e. changes in income distribution do not necessarily affect growth permanently. Serrano and Freitas (2014) emphasize that a key feature of the Supermultiplier model is the fact that a permanent relation between income distribution and growth is absent. A consequence of this assumption is that it leaves room for policy measures and income distribution determinants not directly related to the economic expansion process, i.e. political, historical and social factors placed outside the scope of the model.

\subsection{Towards Some Convergence between the Sraffian and the post-Keynesian Ideas?}

We could identify many convergence points that bring Sraffians and post-Keynesians closer to each other. These two distinct schools of thought are linked by tradition and history, they agree about policy matters, such as the need for government intervention in the economy. Both schools believe in the same causality link between savings and investment (LAVOIE, 2010).

In addition to this, Sraffians and post-Keynesians highlight the role and importance of effective demand in the short-run and in the long-run. Money and credit are the elements responsible for making the effective demand "free" from savings strings. Both schools also suppose that money supply is endogenous. Both adopt a similar concept of capital and believe that ruling out rigidity of wages or market imperfections will not lead the economy automatically to full employment in the long-run. These are just a few of the similarities pointed out by Lavoie (2010).

Thus, we could ask what makes it so difficult to work on a synthesis of these schools? Or at least to put them together under the same tent? According to Lavoie (2010), this difficulty is related to three assumptions usually associated to Sraffians. The first assumption is that production prices are normal prices, which incorporate a normal profit rate; the second refers to the gravitation of market prices towards production prices; third, there are persistent forces pushing the economy towards long-run positions (gravitation centers). These long-period positions are situations where normal prices and output are at normal levels or where actual rates of capacity utilization equal normal rates of capacity utilization. The last assumption attributed to the Sraffians, and which generates controversies between them and post-Keynesians, is the idea that Sraffians reject the possibility of path-dependence, i.e. long period positions are based on a trend determined ex ante and which is independent of short-run period and variables (LAVOIE, 2010). 
However, for some Sraffians as Ciccone, Serrano and Freitas, realized profit rates can differ from normal profit rates over long periods of time, which is another similarity with some neo-Kaleckians as Lavoie himself, Hein and Van Treeck. The main difference is that for Kaleckians, the actual profit rate can affect the rate of accumulation set by the firms. In turn, for Sraffians this role is absent, since the normal rate of profit is the key variable determining investment in new capital (LAVOIE, 2010). According to Lavoie (2010), there is not a strong reason to keep the Sraffian school apart from the post-Keynesian school, since both recognize that capacity utilization rates can differ from their normal rates both in short and long run.

Regarding the supermultiplier model, we could say that the assumption of "fully adjusted positions" criticized by post-Keynesians, even if an important part of the model, is not required for keeping most of the model's conclusions. As Serrano and Freitas (2014) point out, if the supermultiplier model only generated fully adjusted positions, which do not change, it would not be fruitful for analyzing a demand-led growth process. The supermultipler model admits growth paths in which the actual degree of capacity utilization diverges from normal utilization rates. In addition, Serrano's approach of the supermultipler does not deny the possibility of path-dependence. However, this issue is not addressed under the scope of the model, due to the emphasis in the long-run adjustment process of output to aggregate demand.

Moreover, the treatment of income distribution should not be an issue when trying to bring these approaches closer since both the supermultiplier model and most post-Keynesian models presented here define functional income distribution as an exogenously given variable. Whether the determinants of income distribution relate to conflicting claims or to firms' pricing decisions, the results in terms of modelling are the same. ${ }^{18}$ In this regard, the main difference between both analyses is that while in the supermultiplier approach an exogenous change in income distribution has a permanent effect only on the average growth rate of the economy (since the economy moves back to a fully adjusted position where the utilization rate is the normal rate), in most post-Keynesian (neo-Kaleckian) models, an exogenous change in income distribution has a permanent growth effect due to the endogenous utilization rate.

This review shows that, be in the short run or in the long run, post-Keynesian approaches and the Supermultipler approach both seem to be concerned about the effects of autonomous demand components on economic growth. Besides,

18 It should be noted that, with a few exceptions, these models do not deal with the determinants of income distribution (of functional income distribution) and do not properly explain how income distribution relates to inflation and macroeconomic policies. This consists in another research agenda. For more on empirical studies about the determinants of income distribution see, for instance: Dunhaupt (2013), Stockhammer (2013), Afonso, Schuknecht and Tanzi (2008). For a survey on the main theoretical discussions of income distribution among post-Keynesian authors, see Lavoie (2014). 
despite the criticism to the Sraffian approach regarding the lack of attention drawn to financial factors, Serrano and Freitas (2014) in the end of their paper recognize that "research efforts should focus on the determinants and dynamics (particularly financial) of the trend of growth of different "unproductive" autonomous components of demand" (SERRANO; FREITAS, 2014, p. 21).

As a matter of suggestion, there could be a complementarity between the supermultiplier approach and some post-Keynesian (and neo-Kaleckian) approaches, which emphasize the role of financial factors on autonomous demand components through, for instance, the Stock-Flow Consistent methodology. The common interest in autonomous consumption determinants, found both in the literature reviewed in section 2 and in the supermultipler approach, is a convergence point that could be further explored through SFC models.

\section{Final Considerations}

This paper defends the proposition that Keynesian demand-led models do not necessarily need to be private investment-led ones. Models that abstract from the (unquestionably important, at least in the short run) volatility of private investment, treating it as a rather tamed variable, may be instrumental to the study of dynamic trajectories dominated by the autonomous behavior of other expenditure variables.

As economic modelers of all kinds know, the steady state is a convenient "sci-fi" device, even when they do not naïvely take it as a reliable depiction of "where", giving it enough time, a real economy will be. Nevertheless, the possibility of a steady state does not come without cost. It implies that the model can explore only one growth engine at a time.

But this is not too bad for a start. On the contrary: it will be a difficult and enriching endeavor to build each one of these models. The difficulty arises from the need to take into account the peculiarities of each expenditure variable, including the particular financial constraints each of them faces. The limits to (and effects of) the autonomous growth of personal consumption are very different from (e.g.) the limits to (and effects of) government expenditure.

In our opinion, the most appropriate framework to develop this research is the stock-flow consistent one,${ }^{19}$ for it explicitly models the financial flows and stocks. How else would it be possible to analyze the sustainability conditions (or the possibility of "Minskyan" instability) for each possible growth engine?

We can expect tricky (but interesting) hurdles ahead. On the one hand, at some point, these models must be framed in an open-economy setting. After all,

19 This would, incidentally, unlock the ecumenical potential of stock-flow consistent models as a platform for the dialogue among heterodox economists (SILVA; SANTOS, 2011). 
for most countries, the external constraint is the ultimate one. On the other hand, it would be fruitful to explore models in which two or more growth engines share the leadership, or alternate in it. The first case is obviously an unstable (but interesting and we daresay realistic) one. As in Cole Porter's song, "something's gotta give": in the absence of a steady state, some variables will unavoidably hit an inferior or superior threshold. Behavior will change, causing or following some kind of crisis. But, then, this may eventually create the conditions for a new growth period to start, in which a new variable rules the roost. Are we terribly mistaken in thinking that this would resemble growth processes in the real world?

\section{References}

AFONSO, A.; SCHUKNECHT, L.; TANZI, V. Income distribution determinants and public spending efficiency. Washington, DC: European Central Bank, 2008. (Working Paper, n. 861).

ALLAIN, O. Growth, income distribution and autonomous public expenditures. Paper presented at the first joint conference AHE - IIPPE - FAPE, Political Economy and the Outlook for Capitalism, Paris, July 5-7, 2012.

BARBA, A.; PIVETTI, M. Rising household debt: its causes and macroeconomic implications, a long-period analysis. Cambridge Journal of Economics, v. 33, n. 1, p. 113-137, 2009.

BHADURI, A.; LASKI, K.; RIESE, M. A model of interaction between the virtual and the real economy. Metroeconomia, v. 57, n. 3, p. 412-427, 2006.

BIBOW, J. Financialization of the U.S. household sector: the subprime mortgage crisis in U.S. and global perspective. Macroeconomic Policy Institute, Dusseldorf, n. 3, p. 1-98, June 2010.

BORTIS, H. Institutions, behavior and economic theory: a contribution to the classicalKeynesian political economy. Cambridge: Cambridge University Press, 1997.

BROWN, C. Financial engineering, consumer credit, and the stability of Effective Demand. Journal of Post Keynesian Economics, v. 29, n. 3, p. 427-453, 2007.

CESARATTO, S.; SERRANO, F.; STIRATI, A. Technical change, effective demand and employment. Review of Political Economy, v. 15, n. 1, p. 33-52, 2003.

CHINA STATISTICS PRESS. China statistical yearbook. China: China Statistics Press, 2015. Available in: <http://www.stats.gov.cn/tjsj/ndsj/2015/indexeh.htm>. Access in: December $12^{\text {th }} 2016$.

CICCONE, R. Capacity utilization, mobility of capital and the classical process of gravitation. In: CICCONE, R.; GEHRKE, C.; MONGIOVI, G. (Org.). Sraffa and modern economics. v. 2. London: Routledge, 2011.

CYNAMON, B.; FAZZARI,S. Household debt in the consumer age: sources of growth: risk of collapse. Capitalism and Society, v. 3, n. 2, p. 1- 27, 2008. 
DEJUAN, O. How to escape from the trap of the warranted rate of growth. Albacete: University of Castilla, 2014. (Working paper, n. 1).

DUESENBERRY, J. Income, savings and the theory of consumer behaviour. New York: Harvard University Press, 1949.

DUNHAUPT, P. Determinants of functional income distribution: theory and empirical evidence. Berlin: ILO, Nov., 2013. (Working paper, n. 18).

DUTT, A. Conspicuous consumption, consumer debt and economic growth. In: SETTERFIELD, M. (Ed.). Interactions in analytical political economy: theory, policy and applications. New Jersey: M.E., 2005.

. Maturity, stagnation and consumer debt: a steindlian approach. Metroeconomica, v. 57, n. 3, p. 339-364, 2006.

GIRARDI, D.; PARIBONI, R. Autonomous demand and economic growth: some empirical evidence. Sienna: Department of Political Economy and Statistics of University of Sienna, 2015. (Working paper, n. 714).

GODLEY, W.; LAVOIE, M. Monetary economics: an integrated approach to credit, money, income, production and wealth. New York: Palgrave Macmillan, 2007.

GUTTMANN, R.; PLIHON, D. O endividamento do consumidor no cerne do capitalismo conduzido pelas finanças. Economia e Sociedade, n. especial, p. 576-611, 2008.

HEIN, E. Finance-dominated capitalism, re-distribution, household debt and financial fragility in a Kaleckian distribution and growth model. Berlin: Berlin School of Economics and Law, 2011. (Working paper, n. 11).

HEIN, E.; DODIG, N. Financialisation, distribution, growth and crises: long-run tendencies. Berlin: Berlin School of Economics and Law, 2014. (Working paper, n. 35).

KALECKI, M. The problem of effective demand with Tugan-Baranowski and Rosa Luxembourg. In: Selected essays on the dynamics of the capitalist economy, 1933-1970. Cambridge: Cambridge University Press, 1971a. Originally published in 1967.

. Theory of economic dynamics: an essay on cyclical and long run changes in capitalist economy. London: Allen $\mathcal{Z}$ Unwin, 1954.

. Trend and business cycle. In: Selected essays on the dynamics of the capitalist

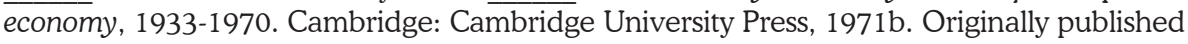
in1968.

KAPELLER, J.; B. SCHUTZ. Conspicuous consumption, inequality and debt: the nature of consumption-driven profit-led regimes. Metroeconomica, v. 66, n. 1, p. 51-70, Apr. 2014a.

Debt, boom, bust: a theory of Minsky-Veblen cycles. Journal of Post Keynesian Economics, v. 36, n. 4, p. 781-814, 2014b.

KEYNES, J. M. The general theory of employment. London: Macmillan, 1973. Originally published in 1937. 
KIM, Y. Emulation and consumer debt: implications of keeping up with the joneses. Dublin: Department of Economics of Trinity College, 2012. (Working paper, n. 1208).

KIM, Y.; SETTERFIELD, M. Debt servicing, aggregate consumption and growth. Dublin: Department of Economics of Trinity College, 2013. (Working paper, n. 1316).

KIM, Y.; SETTERFIELD, M.; MEI, Y. A theory of aggregate consumption. Dublin: Department of Economics of Trinity College, 2013. (Working paper, n. 1301).

LAVOIE, M. Convergence towards the normal rate of capacity utilization in Kaleckian models. Mimeo: University of Ottawa, 2013.

Convergence towards the normal rate of capacity utilization in neo-Kaleckian models: the role of non capacity creating autonomous expenditures. Metroeconomica, v. 67, n. 1, p. 172-201, 2016.

. Post-Keynesian economics: new foundations. Cheltenha: Edward Elgar, 2014.

Should Sraffian economics be dropped out of the Post Keynesian School? In: UNIVESSTY OF ROMA TRE CONFERENCE, 2010, Ottawa. Proceedings... Ottawa: Department of Economics of University of Ottawa, Dec. 2010.

LAVOIE, M.; GODLEY, W. Kaleckian models of growth in a coherent stock-flow monetary framework: a Kaldorian view. Journal of Post Keynesian Economics, v. 24, n. 2, p. 277-311, 2001-02.

ONARAN, Ö.; STOCKHAMMER, E.; GRAFI, L. Financialisation, income distribution and aggregate demand in the USA. Cambridge Journal of Economics, v. 35, n. 4, p. 637-661, 2011.

PALLEY, T. I. Debt, aggregate demand, and the business cycle: an analysis in the spirit of Kaldor and Minsky. Journal of Post Keynesian Economics, v. 16, n. 3, p. 371-390, 1994.

. Inside debt and economic growth: a Cambridge, Kaleckian analysis. Washington, DC: Economics for Democratic $\mathcal{E}$ Open Societies, 2009. (Working paper, n. 2).

PALUMBO, A. Potential output and demand-led growth. In: LEVRERO, E. S.; PALUMBO, A.; STIRATI, A. (Org.). Sraffa and the reconstruction of economic theory: volume two. Aggregate demand, policy analysis and growth. London: Palgrave Macmillan, 2013.

PARK, M. S. Autonomous demand and warranted rate of growth. Contributions to Political Economy, v. 19, n. 1, p. 1-18, 2000.

RYOO, S.; KIM, Y. Income distribution, consumer debt, and keeping up with the joneses: a Kaldor-Minsky-Veblen Model. Dublin: Department of Economics of Trinity College, 2013.

SCHOR, J. Overspent American: why we want what we don't need. New York: Harper Perennial, 1998.

SERRANO, F. Long period effective demand and the Sraffian supermultiplier. Contributions to Political Economy, v. 14, n. 1, p. 67-90, 1995. 
SERRANO, F. The Sraffian supermultiplier. Cambridge: Cambridge University, 1996. Unpublished $\mathrm{PhD}$ thesis.

SERRANO, F.; FREITAS, F. Growth, distribution and effective demand: the supermultiplier growth model alternative. Rio de Janeiro: UFRJ, 2014. (Working paper, n. 2409).

SILVA, A. C.; SANTOS, C. H. Peering over the edge of the short period? The Keynesian roots of stock-flow consistent macroeconomic models. Cambridge Journal of Economics, v. 35, n. 1, p. 105- 124, Jan. 2011.

STOCKHAMMER, E. Why have wage shares fallen? An analysis of the determinants of functional income distribution. In: LAVOIE, M.; STOCKHAMMER, E. (Org.). Wage-led growth: an equitable strategy for economic recovery. London: Palgrave Macmillan, 2013.

TREZZINI, A. The irreversibility of consumption as a source of endogenous demand-driven economic growth. Review of Political Economy, v. 23, n. 4, p. 537-556, 2011.

VAN TREECK, T. Did inequality cause the U.S. financial crisis? Dusseldorf: Macroeconomic Policy Institute, 2012.

VEBLEN, T. The theory of the leisure class. New York: Dover publications, 1994. Originally published in 1899 by Macmillan.

WEN, Y. Granger causality and equilibrium business cycle theory? Federal Reserve Bank of St. Louis Review, v. 89, n. 3, p. 195-205, May/June 2007.

WORLD BANK. China economic update. June 2015. Available in: <https://www.worldbank. org/content/dam/Worldbank/document/EAP/China/ceu_06_15_en.pdf $>$. Access in: December $12^{\text {th }} 2016$.

ZEZZA, G. U.S. growth, the housing market and the distribution of income. Journal of Post Keynesian Economics, v. 30, n. 3, p. 375-401, 2008.

Recebido em: 22/06/2016. Aceito em: 25/01/2017. 